\title{
The magi: Gentiles or Jews?
}

\author{
David C Sim ${ }^{1}$ \\ School of Theology, Australian Catholic University \\ Visiting Scholar: Department of New Testament \\ Faculty of Theology (Sec A), University of Pretoria
}

\begin{abstract}
From the second century onwards the Christian tradition has almost without exception accepted that the magi in Matthew's infancy narrative were Gentiles, and this view also completely dominates modern Matthean studies. Yet this identification of the magi as Gentiles is built upon a number of unconvincing arguments, which fail to stand up to closer scrutiny. A re-assessment of the evidence reveals that the evangelist did not stipulate the racial origins of the magi They may have been Gentiles, but it is equally plausible that they were Jews.
\end{abstract}

\section{INTRODUCTION}

Matthew's story of the magi in 2:1-12 is one of the best-known and most loved narratives in the Gospel. After the birth of Jesus in Bethlehem, in the days of Herod the Great, certain

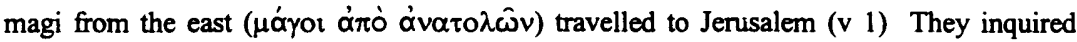
after the new-born King of the Jews, for they had seen his star at its rising (avito tòv

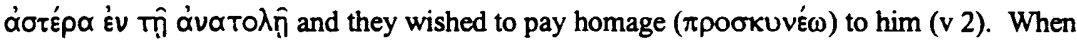
Herod heard of this, he and all Jerusalem were troubled ( $v 3$ ). Herod then inquired of the chief priests and scribes as to where the messiah would be born ( $v 4)$, and they pointed to the prophecy of Mic 5:2 (and 2 Sam 5:2) that he would be borm in Bethlehem in the land of Judah (vv 5-6) Secretly summoring the magi, Herod confirmed the time when they had seen the star of the new king, and he sent them to the ancient city of David with the instruction to reveal to him the whereabouts of the child (vv 7-8). The magi then saw the star they had originally seen, and they followed it until it stopped over the house of Mary and Joseph in Bethlehem (v 9). They greatly rejoiced at seeing the star once more (v 10).

1 Dr D C Sim visited the University of Pretoria as research fellow of Prof Dr Andries G van Aarde, JulyAugust 1999. 
Having successfully concluded their search, they entered the house and saw the child with his mother The magi then fell down and prostrated themselves ( $\pi \rho 0 \sigma k u v \varepsilon \omega)$ before the infant Jesus, and presented him with gifts of gold, frankincense and myrth (v 11) They were then warned in a dream not to see Herod, whose wicked designs become all too clear in the following section of the infancy narrative, and they travelled back to their own country via another route ( $v 12)$.

This story of the mysterious magi with their exotic gifts has always intrigued and delighted readers of the Gospel The fascination with the magi in ancient and mediaeval times is apparent from the many legendary and fanciful traditions that arose with regard to these figures, which found expression in both literature and art. ${ }^{2}$ The meagre details which Matthew provides about the magi were greatly expanded, and these figures eventually became three oriental kings from Persia, named Caspar, Melchior and Balthasar, who visited the baby Jesus thirteen days after his birth In the modem day, nativity scenes, Christmas carols, Christmas cards and Christmas sermons tend to focus more on the magi and their precious gifts than the lowly shepherds who similarly pay homage to the baby Jesus in the Lucan infancy narrative.

In scholarly circles the tradition of the magi in Matthew 2:1-12 poses a range of ques-ions Prominent among these are the story's claims to historicity and the question of the sources Matthew inherited, and on neither issue has a clear consensus emerged Some scholars completely deny the story any historical foundation, ${ }^{3}$ while others conclude that the visit of the magi to the infant Jesus does have a factual basis. ${ }^{4}$ Similarly, while some commentators posit two sources underlying Matt 2:1-12, one dealing with Herod and the other with the magi, which Matthew weaved together, others contend that the pericope was a unity when it reached the evangelist ${ }^{5}$ These are doubtless important issues, which will

\footnotetext{
${ }^{2}$ See the classic study of $\mathrm{H}$ Kehrer, Die heiligen drei Konige in Literatur und Kunst, (2 vols; Hildescheim: Olms, 1976).

${ }^{3}$ See the arguments against historicity listed by U Luz, Das Evangelium nach Matthäus, ( 3 vols; EKKNT; Zürich: Benziger, 1985, 1990, 1997), I, pp 115-16.

- For a recent defence of the historicity of the magi tradition, see D A Hagner, Matthew, (2 vols; WBC 33A and 33B; Dallas: Word Books, 1993, 1996), I, p 25.

5 See J Nolland, "The Sources for Matthew 2:1-12", CBQ 60 (1998), pp 283-300 for a recent discussion of this issue.
} 
continue to occupy the attention of New Testament scholars in the future, but I do not wish to discuss these perennial problems here The focus of the present study is quite different from the issues of historicity and sources.

Our interest resides in the racial or ethnic status of the magi as they appear in Matthew's Gospel. To put the matter in simple terms, did the evangelist intend to depict the magi as Gentiles, or did he expect his readers to identify them as Jews? Many scholars might perhaps be surprised by the very question. The view that the magi were Gentiles has enjoyed almost universal support from the second century onwards. It is first found in the writings of Justin Martyr in the middle of the second century, and it was the standard belief in the writings of the other church fathers. Not surprisingly this view still prevails in popular imagination, and it dominates modern Matthean scholarship. So widespread is the thesis that the magi were Gentiles that very often commentators and exegetes merely presume that it is true, and they make no real attempt to provide any evidence in favour of it. It is important to note that much is built by Matthean scholars upon this particular understanding of the magi. As positive Gentile characters in the Gospel narrative, the magi tell us much about the evangelist's views about the Gentiles and his universalistic perspective. Many scholars make the general point that the magi who pay homage to the new-bom Jewish messiah represent the Gentile world; they therefore foreshadow the Gentiles who believe in Jesus in the time of the evangelist. ${ }^{6}$

It is the purpose of this study to subject this common understanding of the magi to scrutiny. How certain is the claim that the magi are Gentile characters? Appeal to the witness of the patristic sources and/or to the longevity of this view is not permissible The church fathers were themselves Gentiles, and their later interpretation of particular Gospel

- See the major commentaries; Luz, Matthäus, I, p 122; Hagner, Matthew, 1, p 31; W D Davies and D C Allison, A Critical and Exegetical Commentary on the Gospel according to Saint Matthew, (3 vols; ICC; Edinburgh: T \& T Clark, 1988, 1991, 1997), I, pp 228, 253; J Gnilka, Das Matthäusevangelium, (2 vols; HTKNT; Freiburg: Herder, 1986, 1988), I, p 42 and R H Gundry, Matthew: A Commentary on His Handbook for a Mixed Church under Persecution, (Grand Rapids: Eerdmans, revd edn 1994), p 26. Other studies on either the Matthean infancy narrative or the Gospel's universalism make the same point. See A Paul, L'Évangile de L'Enfance selon Saint Matthieu, (Lira la Bible 17; Paris: Cerf, 1968), pp 122-3; E Nellessen, Das Kind und seine Mutter: Struktur und Verkündigung des 2. Kapitels im Matthäusevangelium, (SBS 39; Stuttgart: Katholisches Bibelwerk, 1969), p 137; R E Brown, The Birth of the Messiah: A Commentary on the Infancy Narratives in the Gospels of Matthew and Luke, (Anchor Bible Reference Library; New York: Doubleday, 2nd ed 1993), pp 180-1, 183 and G Tisera, Universalism according to the Gospel of Matthew, (European University Studies 23.482; Frankfurt: Peter Lang, 1993), pp 61, 73-5. 
passages does not always square with the first century, Christian Jewish perspective of the evangelist. ${ }^{7}$ Moreover, longstanding and popular interpretations, despite their longevity, can easily be wrong. The conviction that Matthew was the first Gospel to be written held sway for centuries until it was initially questioned and then abandoned for Marcan priority through sheer weight of evidence There are many other examples of this phenomenon in the discipline of New Testament studies.

While it true that some scholars merely presume the validity of the thesis that the magi were Gentiles, not all commentators follow suit; these exegetes take nothing for granted on this issue, and they do in fact provide evidence that supports the traditional view. After a review of the commentaries and other specialist studies on the Gospel, I have isolated no less than seven distinct arguments that scholars have produced. But before we subject these arguments to closer scrutiny, it is necessary to put them into proper perspective.

The first point to make in this regard is that not one study of the many I consulted produced all seven pieces of evidence. The most offered in any single work was five, but the presence of this many arguments was a rarity; most studies confined themselves to two or three. This is a significant point, for it means that even the supporters of the Gentile status of the magi do not give credence to all the arguments on offer. That is to say, any given scholar accepts the validity of some but not all of the seven arguments involved, and most are impressed by no more than three. Therefore, the seven arguments should not be interpreted as constituent parts of a carefully constructed and widespread cumulative arguent. Secondly, and this follows on from the previous point, there is no agreement at all amongst scholars as to which of the seven arguments are valid. Some scholars make much of a certain piece of evidence, while others ignore it. More importantly, in other cases comentators specifically deny the validity of certain evidence that other scholars consider crucial for building an argument that the magi were Gentiles. The upshot of this is not merely that the supporters of the consensus position disagree among themselves on the issue of the relevant evidence, but that their counter-arguments tend to cancel out the positive arguments

7 So A J Saldarini, Matthew's Christian-Jewish Community, (Chicago Studies in the History of Judaism; Chicago: University of Chicago Press, 1994), pp 11-12. See too D C Sim, The Gospel of Matthew and Christian Judaism: The Histony and Social Setting of the Matthean Community, (Studies of the New Testament and Its World; Edinburgh: T \& T Clark, 1998), pp 296-7. 
they produce. As a result of this, the very hypothesis they are all attempting to validate beomes correspondingly weakened.

In order to call into question the view that the evangelist intended the magi to be taken as Gentiles, it is of course not sufficient to point out the lack of unanimity in the consensus position; it is necessary to examine the seven arguments one by one. And when this is done, it soon becomes clear that not one of these arguments stands up to critical analysis. In some cases the evidence is far more ambiguous than scholars allow, and in other instances it is much overstated. The result of such a critique is that the consensus view of Matthean scholarship that the magi were Gentiles is far less secure than its proponents believe. The consequence of this point is that we must begin to take seriously the alternative hypothesis that the evangelist considered these exotic figures from the east to be Jews and not Gentiles. This conclusion of course has importance repercussions for determining the evangelist's views about the Gentiles and his supposed universalism, and these will be detailed in the conclusions of this study.

\section{THE MAGI AS GENTILES: AN ANALYSIS OF THE ARGUMENTS}

The first argument, which is more often implicit than stated directly, makes the point that, since these people are magi and astrologers, they are by definition Gentiles ${ }^{8}$ Needless to say, this argument carries little conviction. It is based upon two assumptions which are demonstrably incorrect. These assumptions are 1. that Jews were never magi and 2. that Jews were not interested in astrological practices. We shall take each issue in turn.

It can be granted at once that originally all magi were Gentiles. They were members of the Persian priestly caste and the most significant figures in the national religion of Zoroastrianism, and they were regarded as specialists in the interpretation of dreams. In later times, however, the term $\mu$ óyos was considerably expanded, and by the Graeco-Roman period it denoted a whole range of people involved in esoteric practices. A magus could be an individual with supernatural knowledge and powers, especially those gifted in the methods of astrology and divination, or he could be a practitioner of the magical arts. The

8 See Brown, Birth of the Messiah, p 181 n 9; A-J Levine, The Social and Ethnic Dimensions of Matthean Salvation History: "Go nowhere among the Gentiles ..." (Matt 10:5b), (Studies in the Bible and Early Christianity 14; Lewiston: Edwin Mellen, 1988), p 90 and M Davies, Matthew, (Sheffield: Sheffield Academic Press, 1993), p 35. Paul, L'Évangile, pp 116-17 seems to presume that the magi are followers of Zoroaster and thus Gentiles. 
term was also be used in a wholly negative fashion to identify those thought to be deceivers and/or seducers. ${ }^{9}$ At this time a magus need not necessarily be a Persian, let alone a Persian priest, and our sources make reference to a number of Jewish magi.

Two of these references are found in the Acts of the Apostles. In Acts 8:9-24 Luke describes the story of a certain Simon, who practised magic ( $\mu \alpha \gamma \varepsilon \dot{v} \omega$ ) in Samaria and convinced its inhabitants that he possessed the power of God. But when Philip brought the word of God to Samaria, he succeeded in converting the Samaritans who were impressed by his miracles, and even Simon believed and was baptised. Then Peter and John travelled to Samaria to provide the gift of the holy spirit through the laying on of hands, and Simon, wishing to have this special power, offered them money to bestow it upon him. Peter admonished Simon, and the latter begged that he not suffer the punishment of God. The other tradition of a magus in Acts is found in 13:6-11. When Paul, Barnabas and John were in Paphos, they met a man known as Elymas the magician ( $\mu$ '́ $\gamma \circ \varsigma$ ), who is further described as a Jewish false prophet. Elymas opposed them in front of the proconsul, Sergius Paulus, and Paul responded by denouncing him as a son of the devil and then temprarily blinding him. The third instance of a Jewish magus appears in the writings of Josephus (Antiquities 20:142). Felix, the procurator of Judea, fell in love with Drusilla, the wife of the King of Emesa, so he sent his good friend Atomos, a Cypriot Jew and a magus, to convince Drusilla to leave her husband and to marry Felix. These examples of Jewish magi in or near the time of Matthew completely refute the assumption that the magi in the Matthean infancy narrative were necessarily Gentiles.

But what of their interest in astrology? Does not this fact mark the magi as nonJews? The short answer to this question is, not at all. While it is true that some texts from the Hebrew scriptures criticise astrological beliefs (cf Deut 4:19; Isa 47:13-14; Jer 10:2-3) there is ample evidence suggesting that matters had changed significantly by the first century of the common era. In Hellenistic times many Jews had embraced this particular and very popular "science", and we find references to the zodiac and horoscopes in a wide variety of Jewish literature (cf 1 En 72:3; 75:3; 2 En 21:6; 30:6; 4QHoroscope;

" G Delling, "róros", in G Kittel and G Friedrich (eds), Theological Dictionary of the New Testament, (10 vols; Grand Rapids: Eerdmans, 1964-76), IV, pp 356-8. 
4QBrontologion; Treatise of Shem; Sib Or 5:512-31; b Shab. 156ab); indeed Abraham was believed in some Jewish quarters to have been the father of astrology (cf Josephus, Antiquities, 1:158, 167-8; Pseudo-Philo, Biblical Antiquities, 18:5; Pseudo-Eupolemus and Artapanus who are mentioned in Eusebius, Preparation, 9.17.3, 8; 9.18.1). The widespread and important nature of these beliefs is evidenced by the presence of the zodiac and other astrological symbols in the mosaics of early Jewish synagogues. ${ }^{10}$ Although other Jewish traditions upheld the original view of the Hebrew scriptures and disapproved strongly of this foreign intrusion into Judaism (cf 1 En 8:3; Sib Or 3:227-9; 13:69-73; T Sol. 2:2; 4:6; 5:8; 8:1-11; 18:1-42; $b$ Shab. 156b), with some explicitly denying Abraham's association with astrology (Jub 12:16-20; Philo, On Abraham, 69-72, 77, 84; Gen Rab 44:8-12), the fact remains that many Jews had assimilated this originally "pagan" art into the Jewish faith. Even Gentiles acknowledged Jewish expertise in astrology and the importance of Abraham in developing this esoteric practice. ${ }^{11}$ On the basis of this evidence, there is no option but to reject the assumption that the experts in astrology of Matthew 2:1-12 could not have been Jews. $^{12}$

The second argument in favour of the Gentile status of the magi is based upon the information that these figures came from the east to Jenusalem and Bethlehem. Since they derived from a country outside the Jewish homeland, it must be assumed that they were Gentiles. ${ }^{13}$ This argument is as surprising as it is weak. The magi were clearly not residents of the traditional Jewish homeland, but in the first century Jews were hardly confined to this small area. In the preceding centuries, the Jewish people had moved into all part of the

10 For a detailed discussion of the importance of astrology in Jewish literature and architecture, see J H Charlesworth, "Jewish Astrology in the Talmud, Pseudepigrapha, Dead Sea Scrolls, and Early Palestinian Synagogues", HTR 70 (1977), pp 183-200.

"See L H Feldman, Jew and Gentile in the Ancient World, (Princeton, N J; Princeton University Press, 1993), pp 214, 379.

12 So correctly J H Charlesworth, "Treatise of Shem", in J H Charlesworth (ed), The Old Testament Pseudepi-grapha, (2 vols; London: Darton, Longman and Todd, 1983, 1985), I, p 479. The possibility that the magi were Jews is also raised by W K L Lowther, Divine Humanity: Doctrinal Essays on New Testament Problems, (London: SPCK, 1936), pp 44-5 and C S Mann, "Epiphany - Wise Men or Charlatans?, Theology 61 (1958), pp 495-500, esp p 498. Cf too W F Albright and C S Mann, Matthew, (Anchor Bible 26; Garden City, N Y: Doubleday, 1971), p 12.

13 Levine, Social and Ethnic Dimensions, p 90; Tisera, Universalism, pp 54-5 and Gnilka, Matthäusevangelium, I, p 36 Cf too T G Long, Matthew, (Westminster Bible Companion; Louisville: Westminster John Knox Press, 1997), p 17. 
ancient near east and Europe. In earlier times this was a result of forced exile by the Assyrians in the eighth century BCE and the Babylonians in the sixth century BCE, but in the Hellenistic period there was considerable voluntary migration. Josephus could write that the Jews inhabited all parts of the (known) world (Jewish War 2:398; 7:43), and a letter of King Agrippa I to the Emperor Caligula states that the Jews were residents of Egypt, Phoenicia, Syria, Pamphylia, Cilicia, Asia Minor, Europe, Greece, Euboea, Cypress, Crete and, more importantly for our purposes, Babylon and the surrounding areas (Philo, Embassy to Gaius, 281-2). This information is supported by Acts 2:9-11, which refers to Jews from many regions, including Parthia, Media, Elam and Mesopotamia. The numbers of Jews beyond the Euphrates was estimated by Josephus to be in the tens of thousands (Antiquities 11:133; cf $15: 14,39){ }^{14}$ Given that there were many substantial Jewish populations in the countries to the east of Judea, the real possibility exists that the magi from the east were Jews. Certainly the fact that they did not derive from the holy land does not in any way identify them as Gentiles.

The next argument makes the point that the magi refer to Jesus as "the King of the Jews". In the Gospel this particular title appears only on the lips of Gentiles. Pilate asks Jesus whether he is the King of the Jews (27:11), the soldiers of the governor mock Jesus as the King of the Jews (27:29) and the charge against Jesus that is placed at the top of the cross specifies that he is the King of the Jews (27:37). Conversely, the Jews in Matthew's narrative use the alternative term "the King of Israel". As Jesus hangs on the cross, the chief priests, scribes and elders call him "the King of Israel" as they mock and deride him (27:42). The distinction the evangelist draws between the Gentile and Jewish expressions agrees with the remainder of the New Testament documents; Gentiles use 'the King of the Jews' (cf Mark 15:2, 9, 12, 18, 26; Luke 23:3, 37, 38; John 18:33, 39; 19:3, 19, 21), while Jews refer to "the King of Israel" (cf Mark 15:32; John 1:49; 12:13). ${ }^{15}$ It may be questioned, however, whether so much can be inferred from this evidence.

\footnotetext{
14 For more detail on the Jewish residents in Mesopotamia and other lands to the east of the jewish homeland, see E Schürer, The History of the Jewish People in the Age of Jesus Christ (I75 BC-A.D 135), revised by $G$ Vermes, F Millar, M Black and $M$ Goodman, (3 vols in 4 parts; Edinburgh: T \& $T$ Clark, $1973,1979,1986,1987)$, III. 1, pp 3-10, and literature cited there.

15 Davies and Allison, Marthew, I, p 229; Luz, Matthaus, I, p 118; Brown, Birth of the Messiah, p 181 n 9; Tisera, Universalism, pp 55-6; Levine, Social and Ethnic Dimensions, p 90; Gnilka, Matthäusevangelium, I, p 36; Gundry, Matthew, p 27 and, by implication, Hagner, Matthew, I, p 27.
} 
To begin with, while it is true that the New Testament documents are remarkably consistent in attributing one phrase to Jews and another to Gentiles, it cannot be taken for granted that Matthew consciously drew such a sharp distinction between them. In all cases in the passion narrative where Matthew uses "the King of the Jews" and "the King of Israel" he has simply followed his Marcan source. In copying these titles from Mark, we may infer that Matthew saw nothing disagreeable in them, but it is quite impossible to determine now whether he followed Mark at these points with the clear intention of distinguishing between different Jewish and Gentile expressions. It might easily be the case that the evangelist simply reproduced his source without even realising the implications of these different expressions. To infer from these texts in the passion narrative a distinctive linguistic policy on the part of Matthew exceeds the evidence.

This is even more true when we note that the implicit witness of the New Testament documents, that Gentiles used "the King of the Jews" while Jews preferred "the King of Israel", seems not to conform to contemporary Jewish usage. The Jewish historian, Josephus, provides sufficient evidence that the Jews themselves used the former expression. In Antiquities 14:34-6 Josephus refers to a present sent by Alexander Jannaeus (or his son Aristobulus) to Pompey, which bore the inscription, "The Gift of Alexander, the King of the Jews". This episode demonstrates that this particular Jewish king was known as "the King of the Jews". In the next chapter of this work, Josephus relates the story of Manahem the Essene and Herod the Great (15:373-9). The former was a prophet who saw Herod as a child and saluted him as the "King of the Jews". Once again Josephus makes reference to a Jew using this particular title. That Josephus himself agreed with the aptness of this title is evident from Antiquities 16:311, where he himself describes Herod as the King of the Jews. This evidence of Josephus establishes that in the time of Matthew the expression "the King of the Jews' was hardly confined to Gentiles; it was used by Jews as well.

The implications of this conclusion are evident. Matthew too was a Jew, and it is reasonable to suppose that he, like his Jewish contemporaries, drew no ethnic distinction between those who used the titles "the King of the Jews' and "the King of Israel". Jews could use both titles, while Jews and Gentiles could make use of the former. In the light of this, nothing precludes the possibility that Matthew could have depicted the magi as Jews 
who inquired about the whereabouts of the King of the Jews. ${ }^{16}$ The fact that later in the narrative the Gentile Pilate and his soldiers employ the very same title while certain Jews use the alternative "the King of Israel" has no relevance at all.

We may now turn to the fourth argument. The magi must be considered Gentiles because, as learned as they are, they seem not to know the Hebrew scriptures. Their ignorance of the Jewish sacred texts is apparent from the fact that they are forced to ask the location of the messiah's birth-place. ${ }^{17}$ This argument too is less than convincing, and two points can be made against it.

First, the motif of the magi's public inquiry as to the whereabouts of the infant Jewish king in Jerusalem is a necessary device in the plot of the story. It explains how Herod came to hear of the birth of his rival, and it paves the way for the later citation of scripture by the chief priests and scribes. Had the magi known initially where to find the messiah, then the story would have been vastly different. Herod would have remained ignorant of Jesus' birth and the chance to quote Mic 5:2 might have been jeopardised. Matthew might therefore have portrayed the magi as ignorant of the scriptures for the purpose of the story-line. We need not draw the conclusion from this that the magi were Gentiles.

This brings us to the second and more important point. Scholars merely assume that any Jewish magi must have been experts in the Hebrew scriptures, but this assumption needs to be questioned. Not one of the three Jewish magi referred to above is said to have had any expertise in the area of scriptural exegesis. The magus Simon of Acts 8:9-24 was a practitioner of magic and a source of great power, while Elymas was also a magician with perhaps a gift of prophecy (though Luke labels him a false prophet). The Atomos of the Josephus narrative is simply called a magus, and his area of speciality is never spelt out. All magi, be they Jewish or Gentile, devoted themselves completely to their esoteric arts, and it seems unreasonable to expect the Jews among their number to immerse themselves as well in a thorough study of their scriptures. The evangelist specifies very clearly that the magi who visited Jesus were experts in astrology and the movements of the stars, and perhaps as

\footnotetext{
${ }^{16}$ Albright and Mann, Matthew, p 12.

17 Davies and Allison, Matthew, I, p 230 and Brown, Birth of the Messiah, p 181 n 9
} 
well in the interpretation of dreams (2:12). The fact that they were not familiar with current messianic prophecies points not to their Gentile status, but to their intense devotion to their craft. It is significant that the Treatise of Shem, the most complete Jewish astrological work we possess from ancient times, contains no reference at all to the Hebrew scriptures. The implication of the text is that the author was far more preoccupied with astrological practices than with the sacred writings of his people. ${ }^{18}$ Matthew's magi were seemingly no different.

The fifth argument concerns the Old Testament background to the theme of the magi and the star. Many scholars have argued that story of Balaam in Numbers 22-24 has directly influenced this Matthean motif. In the Old Testament episode Balak, the King of Moab, approached a well-known diviner, Balaam of Pethor, to curse the Hebrews who had come to his land. Taking his instructions from God, Balaam travelled to Moab, but instead of cursing the Hebrews he praised and blessed them for being the chosen people of God. In the final oracle he uttered a prophecy conceming a star rising (LXX) from Jacob and a sceptre rising out of Israel (Num 24:17), which will vanquish its enemies. While this particular prophecy probably originally referred to King David, in later Jewish thought it was interpreted along messianic lines (cf CD 7:18-21; 1QM 11:6-7; 4QTest 11-13; T Levi 18:2-3; T Jud. 24:1). The currency of this messianic interpretation in the first and second centuries of the common era explains why the acknowledged messianic leader of the second Jewish revolt against the Romans, Simon bar Kosiba, was given the epithet Bar Kokhba, son of the star, by Rabbi Akiba.

Scholars usually tie together the story of Balaam in Numbers 22-24 and the magi of the Gospel by noting the parallels between them. These correspondences can be described in the following way. ${ }^{19}$ Just as Balaam hailed from the mountains of the east (Num 24:7), so too did the mysterious magi derive from the east. According to Philo, Balaam was himself a magus who possessed the true gift of prophecy (Life of Moses, I, 276-7), and the parallel with the magi in the Matthean infancy story is clear. Balaam prophesied the rising of a star, which was later interpreted as the messiah, while the magi saw the star of the messiah or the

\footnotetext{
${ }^{18}$ Charlesworth, "Treatise of Shem", p 476.

19 See especially Paul, L'Évangile, pp 100-16; Brown, Birth of the Messiah, pp 193-6; Tisera, Universalism, pp 58-9 and Davies and Allison, Matthew, I, pp 230-1. Cf too Gnilka, Matthäusevangelium, I, p 37.
} 
Jewish king at its rising star. Balaam prostrated himself before the angel of the Lord (Num 22:31), and the magi acted in similar fashion in the presence of the infant Jesus. Balak the King was a Transjordanian, a Moabite, while Herod was an Idumean, a descendant of the Tranjordanian Edomites. The former sought the help of Balaam to destroy the Hebrews, but the prophet refused to do so and blessed the people of God instead. In the same manner Herod tried to use the magi to destroy the infant King of the Jews, but they confounded his intentions by honouring the child and presenting him with gifts. After giving his final prophecy, Balaam went back to his place (Num 24:25), and the magi returned to their own country after visiting the new-born messiah.

Scholars draw a number of important conclusions from these correspondences. First, the story of the magi and the star witnesses the fulfilment of an Old Testament messianic text. The star prophesied by Balaam in Numbers 24:17 has finally appeared and testified to the messiahship of Jesus. Secondly, and perhaps more importantly for our purposes, scholars argue that the close parallel between Balaam and the magi indicates that the latter have been modelled on the former. This suggests that the magi, like Balaam, were also Gentiles who acted according to God's will. Just as a Gentile foretold the rising of the messianic star, the Gentile magi act as his successors by bearing witness to the fulfilment of his prophecy. ${ }^{20}$ Are either of these conclusions justified?

Let us begin with the first conclusion. Does the star in Matthew's narrative serve to fulfil the prophecy of Balaam in Numbers 24:17? A closer examination of the two texts reveals that the correspondence is less close than first appearances suggest. The star in the Old Testament oracie is a symbol of the king himself; the king or the messiah of later expectation is the star. In Matthew 2:1-12, by contrast, the star is not the messiah but a real star that points to and reveals the location of the new-born messianic king. ${ }^{21}$

This difficulty has not gone unnoticed, and scholars have offered an explanation for this discrepancy. According to R E Brown, the shift in imagery from a star which symbolises the messiah to a star that heralds his arrival is understandable once the messianic

\footnotetext{
20 Those scholars who emphasise the Gentile status of Balaam and the Matthean magi include Davies and Allison, Matthew, I, p 231; Tisera, Universalism, pp 59-60 and Gundry, Matthew, p 27.

2) Luz, Matthäus, I, p 115 , and Davies, Matthew, p 36.
} 
king has been born and is no longer expected. ${ }^{22}$ This response, however, is far from convincing. There are two other contemporary instances where an individual was considered to be the messiah prophesied in Numbers 24:17, and in both cases the original symbolism was retained. In the Jewish tradition, the obvious example is Bar Kokhba. This messianic figure was identified as the star referred to by Balaam, and he was given a new name which reflected this. The other example comes from the Christian tradition. In Revelation 22:16 the risen and heavenly Jesus refers to himself as the offspring of David, the bright morning star. Jesus, in other words, is the star. It is clear from these examples that neither Jews nor Christians in the time of Matthew saw any need to reinterpret the star of Balaam once their respective messiahs had arrived. Brown's argument therefore has no basis. It is of course possible that Matthew differed from his contemporaries and interpreted the star in Numbers 24:17 in a quite exceptional way, but there is no way of substantiating this possibility. This means that no definitive link can be established between the star of Balaam and the star of the magi.

A further point of relevance is that the evangelist fails to cite the scriptural passage in question; at best we have an allusion to Numbers 24:17..$^{23}$ Yet Matthew employs the technique of the formula quotation, the explicit citation of the prophetic text that has been fulfilled, no less than four times in the infancy narratives (cf 1:22-3; 2:15, 17-18, 23). Why does he not employ this technique in this case? This question is even more pointed given the widespread currency of this particular messianic text in the time of the evangelist. If scholars are to confirm that the star in Matthew's story of the magi was the fulfilment of the star in the Balaam oracle, then they need to explain why the evangelist did not in this case cement the link by using a formula quotation.

In response to this problem, R H Gundry has proposed that Matthew expected his readers "to catch such allusions", ${ }^{24}$ but this is hardly satisfactory If this was Matthew's policy, then we should not expect to find any formula quotations in the Gospel. Gundry needs to show why the evangelist spells out the fulfilment of prophecy in some cases, but is

\footnotetext{
22 Brown, Birth of the Messiah, p 196.

${ }^{23}$ Hagner, Matthew, I, p 25. So too Luz, Matthäus, I, p 115.

24 Gundry, Matthew, p 27.
} 
content with allusions in others W D Davies and D C Allison present an alternative explanation These commentators argue that in chapter 2 of the Gospel all the formula quotations are geographical in nature; they refer in tum to Bethlehem, Egypt, Ramah and Nazareth. It is therefore understandable that no formula quotation is attached to the fulfilment of Numbers 24:17. ${ }^{25}$ This is a rather lame explanation While the formula quotations relating to Bethlehem, Egypt and Nazareth are certainly geographical, the one that mentions Ramah is not. The point of this citation is not the village of Ramah, but the weeping for the children, which parallels the weeping for the infants slaughtered by the soldiers of Herod. Moreover, it is precarious in the extreme to build a case on chapter divisions, since the Gospel was written originally without any verse or chapter divisions. The formula quotation in 1:22-3, which is near the reference to the star in story of the magi, contains no name of a city or country, so it seems rather unwarranted to expect one in this case.

The lack of a formula quotation explicitly citing Numbers 24:17 and its fulfilment in the star of the magi renders quite uncertain the conclusion that the evangelist intended a parallel to be drawn between these motifs. But even if we grant the possibility that he did, and that the star in the Gospel alludes to and so fulfils the oracle of the star in Balaam's prophecy, should we follow the further conclusion of some scholars that Matthew has modelled the magi on the Gentile figure of Balaam? There is a good deal of evidence that suggests we should not.

To begin with, the verbal similarities between Matthew 2:1-12 and Numbers 22-4 are few and far between. This raises the possibility that the thematic parallels between these texts, which were listed above, are more coincidental than deliberate. ${ }^{26}$ But an even greater difficulty for a direct correspondence between Balaam and the magi is that the former, despite his authentic prophetic utterances, was hardly viewed as a positive figure in either the Jewish or Christian traditions. On the contrary, Balaam was universally condemned as an evil Gentile who hatched a plot to lead the Hebrews away from God. This simple point has been completely overlooked by Matthean scholars, who have tended to focus on the oracles of Balaam in Numbers 22-24 to the neglect of the other traditions about this figure.

\footnotetext{
${ }^{25}$ Davies and Allison, Matthew, I, p 235.

${ }^{26}$ So Hagner, Matthew, I, p 25.
} 
This negative view of Balaam appears as early as the book of Numbers. While it is true that in chapters 22-24 alone Balaam is depicted in the main as a righteous instrument of God's prophecy, this portrayal is contradicted by later passages. Immediately after Balaam departed for his own country (Num 24:25) many of the Hebrews mixed with the women of Moab, and were led thereby into idolatry and immorality (Num 25:1-18). In the inevitable execution of judgement which follows, the Hebrews slaughtered the Midianites, including their five kings, and Balaam as well (Num 31:8). The reason for Balaam's execution is explained in 31:16. It was Balaam who convinced the women of Midian (or Moab) to seduce the men of Israel which led to their disobedience to the commandments of God. Scholars usually explain these differing portrayals of Balaam in Numbers 22-24 and 31:8, 16 as the result of different sources, but once Balaam became a maligned figure his reputation continued to decline In Deutoronomy 23:4-5 and Joshua 24:9-10 he is represented not as one who willingly delivered the oracles of God, but as one who tried to curse Israel and was prevented from doing so by God (cf Neh 13:2), while Micah 6:5 associates him with the sin of Israel at Shittim (cf Num 25:1). This trend continued in the later Jewish tradition.

The most severe condemnation of Balaam appears in the writings of Philo. Balaam is depicted as a great example of vanity and foolishness (On Cherubim, I, 32-4), and a soothsayer and diviner who made unsound conjectures (Confusion of Tongues 159). He is furthermore an impious and accursed man, an evil prophet of evil things, who intended to curse the people of Israel but who uttered beautiful blessings and prayers in their favour only because of the direct intervention of God (Migration of Abraham 113-15). In Life of Moses, I, 264-312, Philo records in some detail the biblical story of Balak, Balaam and the sin of the Israelites. While it is true, as some Matthean scholars have pointed out, that Balaam is said to have had inspiration and the prophetic spirit when he uttered his prophecies blessing Israel (276-7, cf 283), Philo also makes it clear that Balaam had no control at all over the words he was saying $(274,283)$; he actually complained that the prophecies were placed in his mouth by God (281), and he retained his initial intention to curse the people of God (286). When Balaam did speak his own mind, he advised Balak that the Israelites could only be defeated by being led away from the law; he therefore proffered the advice that the Moabite women should seduce the Israelite men and lead them to idolatry (Life of Moses, I, 
294-300). For this great wickedness against God and his people Balaam was justly killed (Change of Names 202-3).

A further negative account of Balaam is presented by Josephus (Antiquities 4:10058), though perhaps it is not as hostile as that of Philo. Josephus also makes clear that when Balaam prophesied in favour of the people of Israel he did so because of divine power and not of his own accord (4:118-19). Knowing that God would never allow his people to suffer a great or prolonged calamity, Balaam devised a scheme for Balak whereby the Israelites might be harmed temporarily. He advised the Moabite king to send the fairest women in his kingdom to the Israelites in order to seduce them and lead them away from their worship of the true God (4:126-30). The remainder of the text details the success of this plot (4:13158). The author known as Pseudo-Philo also highlights the role of Balaam in causing the people of God to sin. Balaam knew that Balak's desire to curse Israel went against the will of God, but he still counselled the Moabite king to use his women to seduce and lead astray the Israelites (Biblical Antiquities 18:1-16). This hostility towards Balaam in Judaism continued and even intensified in the rabbinic period. ${ }^{27}$

There is no easing of the condemnation of Balaam in the early Christian traditions. In 2 Peter the author criticises false teachers who carouse and sin, commit adultery and tempt the righteous (2:13-14). These people have followed the way of Balaam (2:15-16). The implication here is that the opponents of the author have committed the same sin as those Israelites who fell for Balaam's plot and were seduced by the women of Moab. A similar use of the Balaam tradition is found in Jude 11. Here certain false Christians, who indulge in licentiousness ( $v 4$ ), defile the flesh ( $(\mathrm{8})$ ), carouse ( $(\mathrm{V} 12)$ and reject authority ( $\mathrm{v}$ $8)$, are said to have abandoned themselves to Balaam's error. A third example is found in Revelation 2:14. In this text the author criticises a number of Christians in Pergamum who hold the teaching of Balaam. They are rebuked for eating food sacrificed to idols and for practising immorality.

Once we collect all the relevant information about Balaam, then the question of the influence of this figure on the evangelist's depiction of the magi takes on a whole new perspective. Matthean scholars largely try to paint Balaam as a righteous Gentile who

27 For more detail, see J R Baskin, Pharaoh's Counsellors: Job, Jethro and Balaam in Rabbinic and Patristic Tradition, (Brown Judaic Studies 47; Chico, Cal: Scholars Press, 1983), pp 77-93. 
mouthed the oracles of God, and they support this interpretation by limiting their discussion of Balaam to Numbers 22-24. As a righteous Gentile, he can then be readily identified with the righteous (Gentile) magi in the Gospel. But it is inherently unlikely that the evangelist viewed Balaam in this fashion. Matthew knew nothing of source criticism, and he would hardly have read Numbers 22-24 independently of the negative traditions about Balaam in Numbers 31:8, 16. He therefore must have known of the Biblical tradition that Balaam was responsible for leading the Hebrews into sin, and he doubtless knew the widespread and hostile contemporary views of this figure. Like the other Jews of his time, he would have discriminated between the holy oracles spoken by Balaam, which God initiated against the will of the speaker, and the character of the man himself. In the light of this, we may now pose the question. Would Matthew have modelled the magi on such a maligned figure in the Jewish and Christian traditions? It stretches credulity to its limit to believe that he would have done so. Consequently, we must conclude that there is no connection at all between this Gentile prophet from the Old Testament and the magi in the Gospel of Matthew. This means of course that this particular argument for the Gentile status of the magi dissolves completely.

Tuming now to the sixth argument, many scholars contend that the gifts of the magi to the baby Jesus demonstrate that these figures were Gentiles. This motif recalls a number of prophetic passages in the Hebrew scriptures, in which the Gentiles will travel to Zion bearing gifts as they submit to the will of God. Of particular importance are Isaiah 60 and Psalm 72. In the former we read; "Nations shall come to your light, and kings to the brightness of your rising ( $(v)$... the wealth of the nations shall come to you (v 5) ... they shall bring gold and frankincense ( $v$ 6)", while the Psalm states; "May the kings of Tarshish and of the isles render him tribute, may the kings of Sheba and Seba bring gifts. May all kings fall down (LXX $\pi$ pookuvijoovorv) before him, all nations serve him (vv 10-11) ... may gold of Sheba be given to him ( $v 15$ )". If these texts underlie the theme of the magis' gifts, then it stands to reason that they are Gentiles. Their journey to Jerusalem represents 
the eschatological pilgrimage of the nations to the holy land, and their gifts to the Jewish messiah reflect the submission of the Gentiles to the one true God. ${ }^{28}$

While it is true that there are some thematic and verbal correspondences between these Old Testament texts and this Matthean motif, it is not certain at all that the evangelist had the former in mind when writing the story of the magi. Once again certainty would have been provided by the use of a formula quotation that drew the reader's attention to these scriptural passages, but none is forthcoming here. ${ }^{29}$ The question posed before with regard to Numbers $24: 17$ is pertinent here as well. Why would the evangelist be content with an allusion to these texts rather than an explicit citation of them? His motivation here is especially difficult to comprehend on the view, shared by most Matthean scholars, that the Gentiles were of paramount importance to the evangelist and that his major intention here was to portray the magi as representatives of believing Gentiles in his own community (see above). ${ }^{30}$

That Matthew did not explicitly have either of these Old Testament texts in mind is indicated by the lack of agreement between them and the magi story. First, neither the Psalm nor Isaiah refers to all three gifts that the magi present to the infant Jesus. The former mentions gold alone (72:15), and the latter gold and frankincense (Isa 60:6; cf Sirach 50:89), but there is no allusion to $\mathrm{mynh}^{31}$ More importantly, both Psalm 72 and Isaiah 60 refer to certain kings making the journey to Zion, while Matthew mentions magi from the east. This is a distinct and significant lack of correspondence. If the evangelist had indeed intended to recall these Old Testament passages, then why did he portray the visitors as magi and not as kings? Surely a reference to three Gentile kings paying homage to the infant Jewish king would have served his purposes better and provided a closer parallel.

28 So Davies and Allison, Matthew, I, pp 249-50; Brown, Birth of the Messiah, pp 187-8; Tisera, Universalism, p 60; Levine, Social and Ethnic Dimensions, p 90; Paul, L'Évangile, pp 118-21; Gnilka, Matthausevangelium, I, p 41; Nellessen, Das Kind, p 74; Gundry, Matthew, pp 31-2; Hagner, Matthew, I, p 31 and Davies, Matthew, p 36.

29 So too Luz, Matthäus, I, p 121.

30 Hagner, Matthew, I, p 31 suggests rather lamely that Matthew did not capitalise on this opportunity by using a formula quotation.

31 Mann, "Wise Men or Charlatans?", p 498. 
With regard to this point, it is interesting to note the later understanding of the magi in Christian tradition. In the Middle Ages the magi were indeed considered to be oriental kings, and this identification was made because of the direct influence of Psalm 72 and Isaiah $60 .{ }^{32}$ If we take this evidence into account, then the fact that Matthew was content to depict the visitors simply as magi and not as kings may well indicate that these Old Testament passages played no part at all in his interpretation of this story.

The final argument for the Gentile status of the magi is that such an identification is consistent with other major Matthean themes, especially the comparison between unbelieving Israel and the believing Gentile world. In 2:2-12 Matthew strongly contrasts the magi, the representatives of the Gentiles, with Herod, the chief priests and the scribes, who signify the disobedient people of God. ${ }^{33}$ This argument relies to a large extent on the assumption that Matthew was completely pro-Gentile and in some respects negative towards the Jewish people and the religion of Judaism. Neither of these points can be taken for granted, however.

In terms of the evangelist's attitude towards the Gentiles, the situation is rather more complex than normally supposed. I have argued elsewhere that the common scholarly claim of Matthew's positive view of the Gentiles is based upon both the misinterpretation of some Gospel passages and the omission from consideration of a number of clear anti-Gentile texts (cf $5: 46-7 ; 6: 7-8 ; 6: 31-2 ; 7: 6 ; 18: 17$ ). ${ }^{34}$ On the question of the relationship between Matthew's Christian Jewish community and Judaism, this too is a complicated subject. The evidence suggests, however, that this group considered itself to be within Judaism even though it was in conflict with formative Judaism. The Gospel neither condemns the religion of Judaism nor all Jews, but it does judge harshly the leaders of formative Judaism, the scribes and the Pharisees. ${ }^{35}$ Since the evangelist does not present a simplistic picture of believing Gentiles and unbelieving Jews, it is impermissible to read such a pattern into his infancy narrative. In view of the conflict between Matthew's community in Antioch and

\footnotetext{
32 Luz, Matthäus, I, p 123. See too C S Mann, "Epiphany - What does it Conmemorate?, Theology 61 (1958), pp 443-7, esp pp 446-7.

${ }^{33}$ So Davies and Allison, Matthew, I, pp 229-30 and Luz, Matthäus, I, p 122.

${ }^{34}$ See Sim, Matthew and Christian Judaism, pp 215-31.

35 See the discussion in Sim, Matthew and Christian Judaism, pp 109-63 and literature cited there.
} 
formative Judaism, it makes good sense to interpret the magi as Jews. Here the evangelist would be contrasting believing Jews from the Diaspora, representing his own community, with unbelieving Jews in the Jewish homeland where formative Judaism was based.

\section{CONCLUSION}

The preceding discussion has attempted to show that not one of the seven arguments produced by scholars to prove that the magi of Matthew 2:1-12 were Gentiles has any validity. Much of the evidence is in fact ambiguous and can apply just as much to the Jews as to the Gentiles. Despite scholarly claims to the contrary, there were Jewish magi and/or Jewish astrologers who lived to the east of the Jewish homeland, and there were Jews who used the expression "the King of the Jews". The fact that the magi appear not to have known the prophecies concerning the birth-place of the messiah need not necessarily identify them as Gentiles. As the Treatise of Shem demonstrates, it is quite unreasonable to expect Jews who devoted themselves to astrology and other esoteric arts to be experts as well in scriptural exegesis. The arguments concerning the fulfilment of certain Old Testament prophecies, the star of Balaam in Numbers 24:17 and the pilgrimage of the nations to Zion in Isaiah 60 and Psalm 72, simply cannot be sustained in view of the absence of formula quotations. Moreover, the claim that Matthew has modelled the magi on the Gentile Balaam is rather incredible, given the universal condemnation of this figure in both Jewish and Christian sources. The final argument, that in this narrative the evangelist establishes a dichotomy between believing Gentiles and unbelieving Jews that is reflected throughout the Gospel, is based upon an incorrect assessment of Matthew's view of both the Gentiles and the Jews.

What conclusions should we draw from this discussion? The first thing to be said is that it would exceed the evidence to suggest that Matthew did not intend the magi to be taken as Gentiles. While none of the seven arguments usually offered in support of this hypothesis is convincing, it must be said that there is no definitive evidence which proves that they could not be Gentiles. This a small and insignificant victory, however. Precisely the same can be said of the alternative hypothesis that the evangelist depicted the magi as Jews. The information Matthew provides about these figures is completely consistent with the thesis that they were Jewish astrologers, but nothing in the story explicitly identifies 
them as Jews and not as Gentiles. The reality of the situation is that the evangelist did not make clear the racial origins of the magi. We have to presume that Matthew assumed this knowledge on the part of his readers. Unfortunately we modern readers are not privy to this information, so we are faced with a choice between the two alternatives.

The very uncertainty of the evidence does, however, have an important consequence. As noted above, scholars make considerable use of the (Gentile) magi in developing an argument for Matthew's positive view of the Gentile world and for substantiating the evangelist's universalistic perspective; it is in fact one of the main pillars on which these theses are built. If, however, the certainty is removed and the Gentile nature of the magi becomes a possibility to be considered alongside the equally plausible possibility that they were Jews, then these hypotheses are dealt a significant blow. From now on scholars must attempt to build their case without any reference to the magi in the Matthean infancy narrative. 